\title{
THE EFFECT OF ATORVASTATIN ON THE COMMON CAROTID ARTERY INTIMA-MEDIA THICKNESS IN PATIENTS WITH ISCHEMIC STROKE
}

\author{
Mojtaba Khazaei ${ }^{1,2}$, Mozhdeh Khosravi' ${ }^{2}$, Shahir Mazaheri' ${ }^{2}$, Mehrdokht Mazdeh ${ }^{1,2}$, \\ Masoud Ghiasian ${ }^{2}$, Mohammad Taheri ${ }^{3}$ and Soudeh Ghafouri-Fard ${ }^{4}$
}

${ }^{1}$ Neurophysiology Research Center, Hamadan University of Medical Sciences, Hamadan, Iran; ${ }^{2}$ Department of Neurology, Hamadan University of Medical Sciences, Hamadan, Iran;

${ }^{3}$ Urogenital Stem Cell Research Center, Shahid Beheshti University of Medical Sciences, Tehran, Iran; ${ }^{4}$ Department of Medical Genetics, Shahid Beheshti University of Medical Sciences, Tehran, Iran

SUMMARY - Occlusion of the initial segment of internal carotid artery is the most common reason for vascular events in the brain. The purpose of this study was to investigate the effect of oneyear treatment with atorvastatin on intima-media thickness (IMT) of carotid arteries as a measure of atherosclerosis in stroke patients. In this prospective interventional study, 44 patients with ischemic stroke were investigated. Patients were treated with atorvastatin $40 \mathrm{mg}$ once a day for one year. IMT of carotid arteries was measured by extracranial Doppler ultrasonography in the distal part of the common carotid artery at the beginning of the study, at 6 months and one year of treatment with atorvastatin. The IMT of both right and left carotid arteries decreased after 6- and 12-month atorvastatin treatment. Based on the results of this study, long-term administration of atorvastatin was associated with reduction in carotid artery IMT in patients with ischemic stroke. Such a decrease in IMT may prevent subsequent stroke or cardiovascular events in these patients.

Key words: Intima-media thickness; Common carotid artery; Atorvastatin; Stroke

\section{Introduction}

Stroke as an extremely frequent disorder accounts for considerable numbers of chronic disability, dementia and deaths cases in the United States ${ }^{1}$. Therefore, it is essential to reduce the risk of stroke by applying preventive methods. Moreover, rehabilitation strategies are important in reducing disabilities in these patients ${ }^{2}$. Ischemic and hemorrhagic strokes are the two main subgroups of stroke with the former subgroup containing almost $80 \%$ of cases. Ischemic stroke is classified into cardioembolic, atherosclerotic, lacunar, and other subtypes based on etiologic factors ${ }^{3}$. Several risk factors have been recognized for stroke based on etio-

Correspondence to: Mohammad Taheri, Shahid Beheshti University of Medical Sciences, Tehran, Iran

E-mail: mohammad_823@yahoo.com

Received December 12, 2018, accepted January 16, 2019 logic classes, among them hypertension, hyperlipidemia, and atrial fibrillation ${ }^{4}$. Occlusion of carotid artery by carotid plaques is an underlying cause of stroke. These plaques are usually slow-developing or dormant for long times but may abruptly change and cause ruptures, fissures, or endothelial corrosions resulting in confined or distant obstructions ${ }^{5}$. Carotid intima-media thickness (IMT), as measured by high-resolution ultrasound techniques, has been generally used as an indicator of atherosclerosis. Several studies have shown the predictive value of IMT in vascular events independently of the routine vascular risk factors ${ }^{6}$. Statins are 3-hydroxy-3-methylglutaryl coenzyme A reductase inhibitors, which are widely used as effective lipid lowering drugs. These drugs can diminish cardiovascular events in several cardiovascular disorders ${ }^{7}$. Statins have beneficial effects by decreasing ischemia, lowering inflammatory responses and ameliorating athero- 
sclerotic events. These effects might also be reflected in a remarkable decrease in IMT following administration of statins ${ }^{8}$. Meta-analyses of available data have indicated substantial reduction of IMT following treatment with some statins such as lovastatin and simvastatin 9 . In the present study, we aimed to evaluate the effects of long-term treatment with atorvastatin on carotid IMT reduction in patients with a history of ischemic stroke.

\section{Patients and Methods}

\section{Patients}

In the current prospective interventional study, 44 patients (21 females and 23 males) with ischemic stroke were enrolled. Patients were referred to Farshchian Hospital, Hamadan during 2016-2017. All patients were treated with atorvastatin $40 \mathrm{mg}$ once a day for one year. The study protocol was approved by the Ethics Committee of Hamadan University of Medical Sciences (Ethics Code: IR.UMSHA.REC.1396.44, Clinical Trial Approval Number: IRCT20170712 9014N173). Written informed consent forms were obtained from all study participants. The inclusion criteria were patient ability to cooperate, history of ischemic stroke and age $>50$ years. Exclusion criteria were creatinine values $>1.5 \mathrm{mg} / \mathrm{dL}$, history of statin use in the previous one month, history of hepatic or muscular side effects following statin taking, taking anticoagulant or other anti-lipid agents, pregnancy and need for endarterectomy or carotid stent.

\section{Measurements}

Patients underwent extracranial Doppler ultrasonography (ECD) with two cylindrical and linear probes. IMT of carotid arteries was measured by a linear probe at the frequency of $5-7 \mathrm{MHz}$ in the distal part of the common carotid artery at the beginning of the study, then at 6 months and one year of treatment with atorvastatin. To increase the accuracy, the artery wall thickness was measured in three regions and the mean values were recorded. Data were collected using a checklist that included demographic data and changes in the carotid artery IMT.

\section{Statistical analyses}

The suitable sample size was determined by $\mathrm{G}^{*}$ Power 3 software considering type I and II errors of 5\% and
$20 \%$, respectively. Data were analyzed using SPSS 16.0 software (IBM, Armonk, NY, USA). Quantitative and qualitative parameters were described by mean \pm standard deviation (SD) and percentage (or proportions), respectively. T test was used for assessment of the effects of intervention on the corresponding parameters. $\mathrm{P}$ values less than 0.05 were considered significant.

\section{Results}

The mean age \pm SD of study participants was 68.6 years. There was no significant age difference between female and male participants $(68 \pm 8.9$ vs. $69.2 \pm 10.5$, $\mathrm{p}=0.695)$. The IMT of both right and left carotid arteries decreased after 6- and 12-month treatment with atorvastatin. Table 1 shows the IMT values after treatment with atorvastatin.

We also assessed the effects of treatment on the mentioned parameters in male and female subjects separately (Table 2). The IMT of the right carotid was not significantly different before treatment and after 6 -month treatment in female subjects $(\mathrm{p}=0.229)$. However, 12-month treatment with atorvastatin resulted in a significant decrease in IMT of both carotids in both male and female subjects.

\section{Discussion}

Carotid IMT has been recognized as an eminent alternative marker of subclinical atherosclerosis ${ }^{10}$ and cardiovascular diseases ${ }^{11}$ in diverse clinical settings. Meanwhile, statins have been shown to alleviate atherosclerotic processes and reduce carotid $\mathrm{IMT}^{9}$. In the current study, we assessed long-term effects of atorvastatin on IMT of carotid arteries in patients with previous ischemic stroke. Recurrent stroke is a devastating event, which is associated with high mortality and morbidity. The pathogenesis of this condition is most likely multifactorial and many recurrences cannot be explained by the routine risk assessments. However, some studies have indicated that common carotid IMT is an independent predictor of stroke recurrence $^{12}$. Furthermore, Lorenz et al. have reported that carotid IMT is a robust forecaster of imminent vascular events. Notably, the relative risk of each IMT change was somehow greater for the endpoint stroke than for myocardial infarction ${ }^{13}$. Ultrasound assessment of carotid IMT is a noninvasive method for eval- 
Table 1. Intima-media thickness (IMT) values after atorvastatin treatment

\begin{tabular}{|l|l|l|l|l|l|}
\hline & Before treatment & $\begin{array}{l}\text { After 6-month } \\
\text { treatment }\end{array}$ & $\begin{array}{l}\text { p value } \\
(\mathrm{t} \text { test })\end{array}$ & $\begin{array}{l}\text { After 12-month } \\
\text { treatment }\end{array}$ & $\begin{array}{l}\text { p value } \\
(\mathrm{t} \text { test })\end{array}$ \\
\hline Right carotid IMT & $0.86 \pm 0.19$ & $0.79 \pm 0.14$ & 0.001 & $0.73 \pm 0.15$ & 0.001 \\
Left carotid IMT & $0.92 \pm 0.19$ & $0.83 \pm 0.15$ & 0.001 & $0.77 \pm 0.13$ & 0.001 \\
Both carotids IMT & $0.89 \pm 0.19$ & $0.81 \pm 0.15$ & 0.001 & $0.75 \pm 0.14$ & 0.001 \\
\hline
\end{tabular}

Table 2. Intima-media thickness (IMT) values after treatment with atorvastatin according to patient gender

\begin{tabular}{|c|c|c|c|c|c|c|c|c|c|c|}
\hline \multicolumn{6}{|c|}{ Males } & \multicolumn{5}{|c|}{ Females } \\
\hline $\begin{array}{l}\text { p value } \\
\text { ( } t \text { test })\end{array}$ & $\begin{array}{l}\text { After } \\
12 \text {-month } \\
\text { treatment }\end{array}$ & $\begin{array}{l}\mathrm{p} \text { value } \\
\text { (t test) }\end{array}$ & $\begin{array}{l}\text { After } \\
6 \text {-month } \\
\text { treatment }\end{array}$ & $\begin{array}{l}\text { Before } \\
\text { treatment }\end{array}$ & $\begin{array}{l}\mathrm{p} \text { value } \\
\text { ( } \mathrm{t} \text { test })\end{array}$ & \begin{tabular}{|l|} 
After \\
12 -month \\
treatment
\end{tabular} & $\begin{array}{l}p \text { value } \\
\text { ( } t \text { test })\end{array}$ & $\begin{array}{l}\text { After } \\
6 \text {-month } \\
\text { treatment }\end{array}$ & $\begin{array}{l}\text { Before } \\
\text { treatment }\end{array}$ & \\
\hline 0.023 & $0.75 \pm 0.16$ & 0.229 & $0.80 \pm 0.09$ & $0.84 \pm 0.17$ & 0.001 & $0.7 \pm 0.14$ & 0.001 & $0.78 \pm 0.7$ & $0.88 \pm 0.21$ & $\begin{array}{l}\text { Right carotid } \\
\text { IMT }\end{array}$ \\
\hline 0.001 & $0.79 \pm 0.11$ & 0.001 & $0.85 \pm 0.10$ & $0.94 \pm 0.15$ & 0.001 & $0.76 \pm 0.14$ & 0.008 & $0.81 \pm 0.19$ & $0.9 \pm 0.19$ & $\begin{array}{l}\text { Left carotid } \\
\text { IMT }\end{array}$ \\
\hline
\end{tabular}

uation of the degree of arteriosclerosis, the risk of upcoming stroke, and appraisal of the efficacy of drug therapies ${ }^{14}$. In the current prospective study, we demonstrated the beneficial effects of atorvastatin in reducing carotid IMT at both time points in male subjects.

Our results are in accordance with a previous metaanalysis, which showed that treatment with atorvastatin significantly decreased carotid IMT in Chinese patients with type 2 diabetes ${ }^{15}$. Furthermore, Fang et al. showed that high-dose atorvastatin $(40 \mathrm{mg})$ was superior to low-dose $(10 \mathrm{mg})$ atorvastatin in reducing carotid $\mathrm{IMT}^{15}$. Based on these results, we only checked the effects of high-dose atorvastatin in our cohort of patients. Previous studies report controversial results regarding the effect of atorvastatin on IMT, which might be due to short duration of drug administration $^{15}$. For instance, Kim et al. showed that 6-month use of statins amended endothelial function in patients with variant angina, but they did not detect significant decrease in carotid IMT in their patients ${ }^{7}$. Such duration-based effects were also demonstrated in our study. Although this intervention did not reduce right carotid IMT in female subjects after 6 months, one-year treatment with atorvastatin significantly decreased IMT of both arteries in both sexes. Therefore, we conclude that long-term administration of atorvastatin increases its effects in all patients and might decrease the risk of future strokes. However, additional studies are needed to verify our results in larger sample sizes. Moreover, assessment of long-term side effects of atorvastatin is needed. The current study had the strength of accurate measurement of artery wall thickness in three regions of the artery and assessment of patients from a similar ethnic group, which is expected to decrease the effects of confounding variables. However, our study had some limitations including the lack of control group and inclusion of patients of distinct age range, which might limit the generalizability of the results.

\section{Acknowledgment}

The current study was supported by a grant from Hamadan University of Medical Sciences.

\section{References}

1. Roger VL, Go AS, Lloyd-Jones DM, Adams RJ, Berry JD, Brown TM, et al. Heart disease and stroke statistics - 2011 update: a report from the American Heart Association. Circulation. 2011 Feb 1;123(4):e18-e209. doi: 10.1161/CIR. 0b013e3182009701

2. Vidovic M, Sinanovic O, Sabaskic L, Haticic A, Brkic E. Incidence and types of speech disorders in stroke patients. Acta Clin Croat. 2011 Dec;50(4):491-4.

3. Adams HP Jr, Bendixen BH, Kappelle LJ, Biller J, Love BB, Gordon DL, et al. Classification of subtypes of acute ischemic stroke. Definitions for use in a multicenter clinical trial. 
TOAST. Trial of Org 10172 in Acute Stroke Treatment. Stroke. 1993 Jan;24(1):35-41. doi: 10.1161/01.str.24.1.35

4. Boehme AK, Esenwa C, Elkind MSV. Stroke risk factors, genetics, and prevention. Circ Res. 2017 Feb 3;120(3):472-95. doi: 10.1161/CIRCRESAHA.116.308398

5. Rothwell PM. Atherothrombosis and ischaemic stroke. $\mathrm{Br}$ Med J. 2007 Feb 24;334(7590):379-80. doi: 10.1136/bmj. 38964.489051.80

6. Lorenz MW, von Kegler S, Steinmetz H, Markus HS, Sitzer M. Carotid intima-media thickening indicates a higher vascular risk across a wide age range: prospective data from the Carotid Atherosclerosis Progression Study (CAPS). Stroke. 2006 Jan 1;37(1):87-92. doi: 10.1161/01.STR.0000196964. 24024.ea

7. Kim KH, Cho SH, Yim YR, Lee KJ, Yum JH, Yoon HJ, et al. Effects of low dose versus high dose statin therapy on the changes of endothelial function and carotid intima-media thickness in patients with variant angina. J Cardiovasc Ultrasound. 2013;21(2):58-63. doi: 10.4250/jcu.2013.21.2.58

8. Riccioni G. Statins and carotid intima-media thickness reduction: an up-to-date review. Curr Med Chem. 2009;16(14):1799805. doi: 10.2174/092986709788186183

9. Huang Y, Li W, Dong L, Li R, Wu Y. Effect of statin therapy on the progression of common carotid artery intima-media thickness: an updated systematic review and meta-analysis of randomized controlled trials. J Atheroscler Thromb. 2013;20 (1):108-21. doi: $10.5551 /$ jat. 14001
10. Jung CH, Baek AR, Kim KJ, Kim BY, Kim CH, Kang SK, et al. Association between cardiac autonomic neuropathy, diabetic retinopathy and carotid atherosclerosis in patients with type 2 diabetes. Endocrinol Metab (Seoul, Korea). Dec 2013;28(4): 309-19. doi: 10.3803/EnM.2013.28.4.309

11. Sibal L, Agarwal SC, Home PD. Carotid intima-media thickness as a surrogate marker of cardiovascular disease in diabetes. Diabetes Metab Syndr Obes. 2011 Jan 19;4:23-34. doi: 10.2147/DMSO.S8540

12. Talelli P, Terzis G, Katsoulas G, Chrisanthopoulou A, Ellul J. Recurrent stroke: the role of common carotid artery intimamedia thickness. J Clin Neurosci. 2007 Nov;14(11):1067-72. doi: 10.1016/j.jocn.2006.06.019

13. Lorenz MW, Markus HS, Bots ML, Rosvall M, Sitzer M. Prediction of clinical cardiovascular events with carotid intimamedia thickness: a systematic review and meta-analysis. Circulation. 2007 Jan 30;115(4):459-67. doi: 10.1161/CIRCULATIONAHA.106.628875

14. Gaarder M, Seierstad T. Measurements of carotid intima media thickness in non-invasive high-frequency ultrasound images: the effect of dynamic range setting. Cardiovascular ultrasound. 2015 Dec 1;13(1):5. doi: 10.1186/1476-7120-13-5

15. Fang N, Han W, Gong D, Chen Z, Fan Y. Atorvastatin treatment for carotid intima-media thickness in Chinese patients with type 2 diabetes: a meta-analysis. Medicine. 2015 Nov;94:44. doi: 10.1097/MD.0000000000001920

Sažetak

\section{UČINAK ATORVASTATINA NA DEBLJINU ARTERIJSKE INTIME MEDIJE U BOLESNIKA S ISHEMIJSKIM MOŽDANIM UDAROM}

\section{Khazaei, M. Khosravi, Sh. Mazaheri, M. Mazdeh, M. Ghiasian, M. Taheri i S. Ghafouri-Fard}

Blokada početnog dijela interne karotidne arterije najčešći je razlog vaskularnih ispada u mozgu. Namjera ovoga istraživanja bila je ispitati učinak jednogodišnje terapije atorvastatinom na debljinu intime medije (intima-media thickness, IMT) karotidnih arterija kao mjere ateroskleroze kod bolesnika s moždanim udarom. U ovoj prospektivnoj intervencijskoj studiji ispitana su 44 bolesnika s ishemijskim moždanim udarom. Bolesnici su liječeni atorvastatinom, $40 \mathrm{mg}$ jedanput na dan kroz jednu godinu. IMT karotidnih arterija mjeren je ekstrakranijskom Doppler ultrasonografijom u distalnom dijelu zajedničke karotidne arterije na početku istraživanja te nakon 6 mjeseci i 12 mjeseci liječenja atorvastatinom. Zabilježeno je sniženje IMT i u desnoj i u lijevoj karotidnoj arteriji nakon 6 mjeseci i 12 mjeseci liječenja atorvastatinom. Rezultati ovoga istraživanja pokazuju da je dugotrajno uzimanje atorvastatina bilo udruženo sa smanjenjem IMT karotidnih arterija u bolesnika s ishemijskim moždanim udarom. Takvo sniženje IMT moglo bi spriječiti naknadni moždani udar ili kardiovaskularne ispade kod ovih bolesnika.

Ključne riječi: Debljina intime medije; Zajednička karotidna arterija; Atorvastatin; Moždani udar 